\title{
Assessment of acute radiation therapy-related cardiotoxicity by cardiovascular magnetic resonance
}

\author{
Julius Traber $^{1 *}$, Robert Krempien², Jeanette Schulz-Menger ${ }^{1}$, Florian von Knobelsdorff-Brenkenhoff ${ }^{1}$ \\ From 19th Annual SCMR Scientific Sessions \\ Los Angeles, CA, USA. 27-30 January 2016
}

\section{Background}

Radiation therapy is an effective and broadly applied adjuvant in the treatment of many malignancies. Collateral radiation exposure to the heart can result in relevant cardiac disease, which might not be manifest until years after treatment. Aim of this study was to test whether cardiovascular magnetic resonance (CMR) identifies signs of early cardiac injury.

\section{Methods}

We prospectively applied CMR at $1.5 \mathrm{~T}$ before (a), at half-time (b) and after radiation therapy (c) in patients with different thoracic malignancies. Besides SSFP-based cine imaging for cardiac morphology and function, we performed pre- and post-contrast T1-mapping (MOLLI) as well as late gadolinium enhancement (LGE) imaging for tissue characterization. T1-times were assessed in a mid-ventricular short axis. LV Ejection Fraction (LVEF) and the partition coefficient $\lambda$ were calculated.

\section{Results}

Ten patients ( 5 male, $51.4 \pm 16.3$ years) were included. One patient was excluded due to an unknown metallic implant, one declined at baseline, one at half-time and one at after radiation therapy examination. Mean heart dose was $11.5 \pm 9.6 \mathrm{~Gy}$. LVEF of all patients was above $50 \%$ at baseline. It dropped below $50 \%$ in one patient at half-time and in two patients at after radiation examination (Figure 1). The frequency of pericardial effusions increased (a: none, b: one, c: two). LGE was positive in two cases at baseline, no new LGE occurred during radiation therapy. Native T1-times as well as $\lambda$ were in

${ }^{1}$ Charité Medical Faculty and HELIOS clinics, Working group Cardiovascular MRI, Berlin, Germany

Full list of author information is available at the end of the article

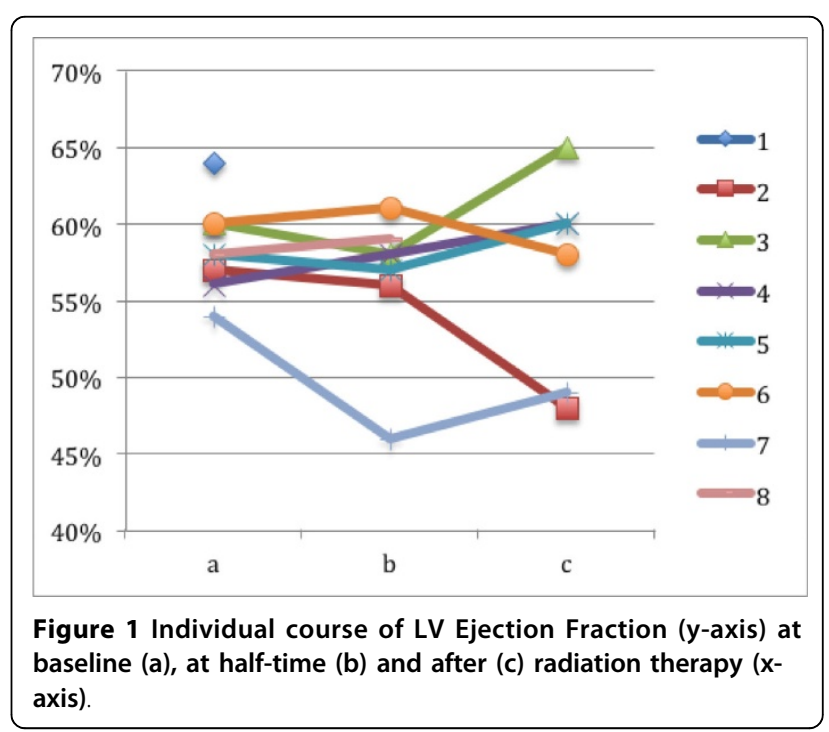

the range of reference values at all time points and showed no major change (Table 1).

\section{Conclusions}

The incidence of pericardial effusion increased during radiation therapy, while CMR tissue analysis failed to identify early myocardial injury in this small number of patients. The LVEF changed in some individuals. A larger trail and subgroup analysis is needed for further differentiation.

\section{Authors' details}

${ }^{1}$ Charité Medical Faculty and HELIOS clinics, Working group Cardiovascular MRI, Berlin, Germany. ${ }^{2}$ Radiation Therapy, HELIOS clinics Berlin Buch, Berlin, Germany. 
Table 1 Mean course of LVEF, native T1 times and $\lambda$

\begin{tabular}{cccc}
\hline & Baseline & Half-time of radiation therapy & After radiation therapy \\
\hline LVEF [\%] & $58 \pm 3$ & $56 \pm 5$ & $57 \pm 7$ \\
Native T1 [ms] & $966 \pm 39$ & $956 \pm 14$ & $968 \pm 72$ \\
$\lambda$ & $0.41 \pm 0.04$ & $0.41 \pm 0.02$ & $0.42 \pm 0.02$ \\
\hline
\end{tabular}

Published: 27 January 2016

doi:10.1186/1532-429X-18-S1-P257

Cite this article as: Traber et al:: Assessment of acute radiation therapyrelated cardiotoxicity by cardiovascular magnetic resonance. Journal of Cardiovascular Magnetic Resonance 2016 18(Suppl 1):P257.

Submit your next manuscript to BioMed Central and take full advantage of:

- Convenient online submission

- Thorough peer review

- No space constraints or color figure charges

- Immediate publication on acceptance

- Inclusion in PubMed, CAS, Scopus and Google Scholar

- Research which is freely available for redistribution

Submit your manuscript at www.biomedcentral.com/submit 